\title{
Prevalence study on Trypanosoma vivax in dairy cattle in the Western region on the State of Paraná, Brazil
}

\section{Estudo da prevalência de Trypanosoma vivax em bovinos leiteiros da região Oeste do Estado do Paraná, Brasil}

\author{
Alessandra Snak ${ }^{1 *}$; Arielle Aparecida Lara ${ }^{2}$; Felipe Gustavo Garcia ${ }^{3}$; \\ Euclides Mario Pieri ${ }^{3}$; Júlia Angélica Gonçalves da Silveira ${ }^{4}$; Silvia Cristina Osaki ${ }^{5}$
}

\begin{abstract}
In Brazil, Trypanosoma vivax is present in several states. The disease is endemic in Pantanal and Minas Gerais. In Paraná there is still no report of the parasite, but due to the state borders with Mato Grosso do Sul, São Paulo, Paraguay and Argentina, it is believed that the protozoan circulates in the region without diagnosis. The objective of this study was to investigate the prevalence of $T$. vivax in dairy cattle in the western region of Paraná. For this purpose, 600 blood samples and 400 serum samples were collected from dairy cattle, distributed in 60 and 40 properties, respectively. While buffy coat smears were performed on blood samples, serum samples were used in Indirect Immunofluorescence Reaction. All samples, in both techniques, presented negative results for T. vivax. These results indicate that the studied hemoprotozoan is not circulating among the cattle in the western region of Paraná. However, future work evolving beef cattle must be carried out and preventive measures should be adopted in order to avoid the entry of the parasite in the State of Paraná.
\end{abstract}

Key words: IFAT. Buffy coat. Hemoprotozoan. Smear. Trypanosomiasis.

\section{Resumo}

No Brasil o Trypanosoma vivax está presente em diversos Estados. No Pantanal e em Minas Gerais a doença é endêmica. No Paraná ainda não há relato do parasito, porém como o Estado possui fronteiras com Mato Grosso do Sul, São Paulo, Paraguai e Argentina acredita-se que o protozoário circula na região sem diagnóstico. $\mathrm{O}$ objetivo desse trabalho foi pesquisar a prevalência do $T$. vivax em bovinos leiteiros da região Oeste do Paraná, sendo esse o primeiro estudo com o protozoário no Estado. Para isso, foram coletadas 600 amostras de sangue total e 400 amostras de soro sanguíneo de bovinos leiteiros, distribuídos em 60 e 40 propriedades, respectivamente. Foi realizado esfregaço de papa leucocitária das amostras de sangue e Reação de Imunofluorescência Indireta das amostras de soro. Todas as amostras, em ambas as técnicas, apresentaram resultado negativo para o T. vivax. Esses resultados indicam que o hemoprotozoário pesquisado não está circulando entre os bovinos de leite da região Oeste do Paraná. Porém, novos trabalhos com bovinos de corte devem ser realizados e medidas preventivas devem ser adotadas para evitar a entrada do parasito no Estado do Paraná.

Palavras-chave: Esfregaço papa leucocitária. Hemoprotozoário. RIFI. Tripanossomose.

${ }^{1}$ Discente de Doutorado, Universidade do Estado de Santa Catarina, UDESC, SC, Brasil. E-mail: alessandra.snak@hotmail.com

2 Discente de Mestrado, Universidade Federal do Paraná, UFPR, Palotina, PR, Brasil. E-mail: ariellelara91@gmail.com

${ }^{3}$ Médicos Veterinários, UFPR, Palotina, PR, Brasil. E-mail: felipedo402@gmail.com; euclides-mp@hotmail.com

${ }^{4}$ Prof ${ }^{a}$, Universidade Federal de Minas Gerais, UFMG, Belo Horizonte, MG, Brasil. E-mail: jangelicags@gmail.com

${ }_{5}$ Prof ${ }^{\text {a }}$,UFPR, Palotina, PR, Brasil. E-mail: silvia_cristinao@yahoo.com.br

* Author for correspondence 
Trypanosoma vivax is a flagellate hemoprotozoon that infects mainly cattle, in which it causes severe anemic conditions and abortion. In addition to infecting cattle, it may also infect small ruminants, horses and wild animals (DAGNACHEW; BEZIE, 2015).

In Brazil, the presence of this protozoan has been reported in several states. The Pantanal region in the state of Mato Grosso do Sul and the states of Minas Gerais and São Paulo are the locations of the largest numbers of cases of disease caused by T. vivax (MARTINS et al., 2008; CADIOLI et al., 2012; BARBIERI et al., 2016).

The state of Parana is located in the southern region of Brazil, with borders with three states (Santa Catarina, São Paulo and Mato Grosso do Sul) and two countries (Paraguay and Argentina). It is the third largest milk producer in Brazil, only behind the states of Minas Gerais and Rio Grande do Sul. In addition to milk production, it also has major production of beef cattle and is in ninth place in the national ranking (IBGE, 2016). So far, no cases of trypanosomiasis in cattle in Paraná have been recorded, maybe through lack of laboratory diagnoses. However, large-scale transport of animals take place, especially from Mato Grosso do Sul to Paraná, and it can be supposed that the disease does occur.
Therefore, the present study was the first to investigate the occurrence of T. vivax in dairy cattle sampled in the state of Paraná.

This study was approved by the Ethics Committee for Animal Use of the Federal University of Paraná, Palotina sector, under protocol number 50/2014.

The western region is the main dairy producer in the state of Paraná, with the cities of Marechal Cândido Rondon, Toledo and Cascavel being the largest producers in the region, and ranked among the 15 cities with the largest milk production in the country (IBGE, 2016). In addition to the importance of milk production, the region is close to the border of two countries, Argentina and Paraguay, and one state, Mato Grosso do Sul, so this region was chosen for the study of $T$. vivax prevalence.

The sample size was defined through calculations using the EpiInfo software (version 7.2.0.1), taking the expected prevalence to be $50 \%$ and expected maximum error $6 \%$, with a $95 \%$ confidence interval and design effect (DEFF) of 1.5. This showed that the minimum number of samples to be collected was 400. Therefore, 400 animals were used for serological tests and 600 for evaluation of buffy coat smears. These animals were on farms in four municipalities in the western region of Paraná: Cascavel, Marechal Cândido Rondon, Palotina and Toledo (Figure 1).

Figure 1. Cities where blood samples from dairy cows were collected for Trypanosoma vivax exams.

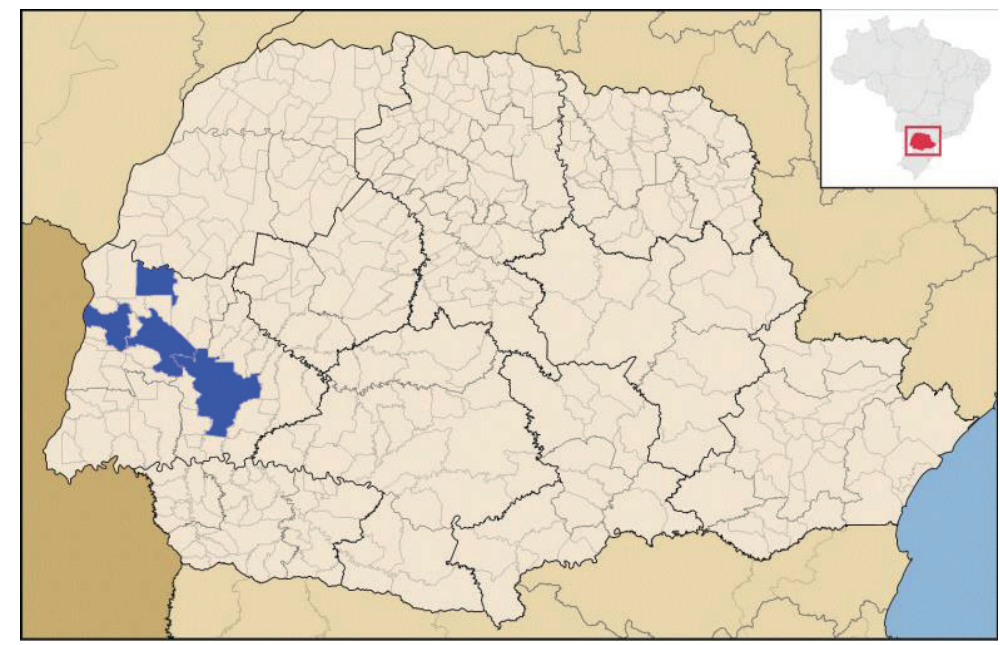

Source: Wikipedia (2017). 
These farms were selected randomly and ranged in size from small to large-scale producers. It was stipulated that samples should be collected from 10 animals on each farm and, thus, samples were taken from 60 farms for evaluation of buffy coat smears and from 40 for serological tests (Table 1).

Table 1. Distribution of farms and animals sampled in different municipalities in the western region of Paraná, Brazil.

\begin{tabular}{lcccc}
\hline Municipality & No. of farms sampled & $\begin{array}{c}\text { No. of animals } \\
\text { sampled }\end{array}$ & No. of farms sampled & $\begin{array}{c}\text { No. of animals } \\
\text { sampled }\end{array}$ \\
\hline Cascavel & 18 & 180 & 18 & 180 \\
Toledo & 19 & 190 & 9 & 90 \\
M. C. Rondon & 17 & 170 & 7 & 70 \\
Palotina & 6 & 60 & 6 & 60 \\
\hline Total & 60 & 600 & 40 & 400 \\
\hline
\end{tabular}

The blood samples thus collected were then sent to parasitic diseases laboratories at the Federal University of Paraná and the Federal University of Minas Gerais, for evaluation of the buffy coat smears and serological tests, respectively, to be performed.

To find the antigen, the Buffy Coat was extracted, a term for the leucoplatelet layer, because after the centrifugation, the protozoan, by density difference, is close to this layer. For this purpose, the blood was centrifuged with anticoagulant at $1500 \mathrm{rpm}$ for $10 \mathrm{~min}$, then it was possible to observe the formation of three layers, one containing the red blood cells, the other the leukocytes and platelets, and the last one consisted of plasma. The whole plasma was then removed (surface layer) and a drop of the buffy coat was placed on a slide and squashed by a micropipette. The slide was dried at room temperature and stained with Panopticus (Laborclin), the reading was performed under an optical microscope in a 1000-times increase.

The serological method performed for Indirect Fluorescent Antibody Test (IFAT). Serum samples were diluted with 1:80 ratio PBS (saline phosphate buffer), followed by $20 \mu \mathrm{L}$ addition to each pool of immunofluorescence slide and incubated for 30 minutes at $37^{\circ} \mathrm{C}$ in a humid chamber, followed by 5 min washing with PBS and distilled water, the slide was dried and then $20 \mu \mathrm{L}$ conjugated anti-bovine IgG labeled with fluorescein isothiocyanate_Sigma) diluted 1:200 with Evans Blue (1:50 in PBS Tween) was added and incubated for $30 \mathrm{~min}$ at $37^{\circ} \mathrm{C}$. The washings were then performed again as described above and the slide dried. Thereafter, a coverslip was placed with two drops of buffered glycerin and read under an epifluorescence microscope at a 400-times increase. Samples with total fluorescence at dilutions $\geq 1: 80$ are considered positive (GARCIA et al., 2006).

From buffy coat smear analysis on 600 samples and serological tests on 400 serum samples from dairy cattle in the western region of Paraná, it was found that all the samples presented negative results for both evaluations that were used. This result demonstrates that $T$. vivax is not circulating among dairy cattle in this studied region.

The Buffy Coat technique, because it is a parasitological method, has a lower sensitivity when compared to IFAT, but this is used to detect the antigen in the acute phase of the disease, in which the IFAT for IgG detection has a lower sensitivity, increasing in the chronic phase of the 
disease (DAGNACHEW; BEZIE, 2015). Therefore, although the first technique being less sensitive, they complete each other to increase the sensitivity of the diagnosis and avoid a greater number of false negatives, considering the stage of the disease in which it is, acute or chronic.

T. vivax affects greater numbers of dairy cattle (mainly females) than beef cattle. His occurs mostly through iatrogenic transmission, in which humans interfere with and influence transmission of this protozoon. Use of injectable oxytocin during milking is one of the main factors responsible for its dissemination, because of use of infected needles and syringes (CIEP, 2016). Nonetheless, this hemoprotozoon may also affect beef cattle, and this has already been reported from several states (MARTINS et al., 2008). Therefore, studies investigating this parasite in beef cattle in Paraná should also be conducted, given that there is greater volume of transportation between states for beef cattle than for dairy cattle.

Cases of trypanosomiasis in cattle have now been reported from several states in Brazil, especially in the northern, northeastern, centralwestern and southeastern regions (GUEDES et al., 2008; CADIOLI et al., 2012; COSTA et al., 2013; BARBIERI et al., 2016). In the states of Paraná and Santa Catarina there are still no reports of this parasite, but the disease has the capacity to reach these regions rapidly, particularly through transportation of animals between states, which takes place frequently.

In addition to transportation of animals, hematophagous insects such as Tabanidae and Stomoxys calcitrans are among the main agents responsible for transmission of $T$. vivax. These insects are distributed throughout the state of Paraná, and also in neighboring states. Their rate of occurrence increases significantly in the summer, because of climatic conditions that favor their reproduction (BIRHANU et al., 2015; TURCATEL et al., 2007).
One of the main problems regarding trypanosomiasis in Paraná is that it is an exotic disease in this state. Therefore, its impact may reach large proportions, and this is a matter of concern among veterinarians and livestock-rearers, especially because it leads to major decline in production and loss of many animals (PAIVA et al., 2000; CARVALHO et al., 2008). In 1999, the losses in the Brazilian Pantanal region caused by this parasite reached 190 million dollars (SEIDL et al., 1999).

To avoid entry of this protozoon into this region of Paraná, disease prevention and control measures need to be implemented. Thus, transportation of suspect animals or animals from regions where the disease is endemic (such as the Pantanal) should be avoided. Control measures against hematophagous insects need to be implemented, especially in the summer, when the numbers of insects increase. Sterile disposable needles should be used and reuse should be avoided, both for blood collection and for vaccination and medication of the animals (SILVA, 2006; ZAPATA et al., 2009; HURTADO et al., 2016).

Furthermore, correct early diagnosing of the disease is important for avoiding widespread dissemination of the protozoon within and between herds. Adequate treatment for the animals affected needs to be implemented, because untreated animals may become asymptomatic clinical carriers of the disease, which would facilitate dissemination even more (HURTADO et al., 2016).

The protozoon T. vivax was not found in the dairy cattle of the western region of Paraná that were evaluated in this survey, through either of the two different diagnostic methods used: the indirect immunofluorescence reaction or the direct buffy coat smear evaluation, techniques used for disease detection in chronic and acute stages respectively.

Since there continues to be no presence of this protozoon in this region, preventive measures should be implemented throughout the region 
in order to avoid entry of $T$. vivax and diminish the losses if entry were to occur, as well as new studies must be carried out to verify the presence or absence of the parasite in other regions of the State, both in dairy and beef cattle. As well as the use of more sensitive techniques can be used, such as PCR (Polymerase Chain Reaction) and LAMP (Loopmediated Isothermal Amplification).

\section{Acknowledgements}

Renata Marques Bagno and Fernanda Rodrigues for help with the IFAT.

\section{References}

BARBIERI, J. M.; BLACON, Y. A. C.; BRUHN, F. R. P.; GUIMARÃES, A. M. seroprevalence of Trypanosoma vivax, Anaplasma marginale, and Babesia bovis in dairy cattle. Ciência Animal Brasileira, Goiânia, v. 17, n. 4, p. 564-573, 2016.

BIRHANU, H.; FIKRU, R.; SAID, M.; KIDANE, W.; GEBREHIWOT, T.; HAGOS, A.; ALEMU, T.; DAWIT, T.; BERKVENS, D.; GODDEERIS, B. M.; BUSCHER P. Epidemiology of Trypanosoma evansi and Trypanosoma vivax in domestic animals from selected districts of Tigray and Afar regions, Northern Ethiopia. Parasites \& Vectors, London, v. 8, p. 212-222, 2015.

CADIOLI, F. A.; BARNABÉ, P. A.; MACHADO, R. Z.; TEIXEIRA, M. C. A.; ANDRÉ, M.R.; SAMPAIO, P. H.; FIDÉLIS JUNIO, O. L.; TEIXEIRA, M. M. G.; MARQUES, L. C. First report of Trypanosoma vivax outbreak in dairy cattle in São Paulo state, Brazil. Revista Brasileira de Parasitologia Veterinária, Jaboticabal, v. 21, n. 2, p. 118-124, 2012.

CARVALHO, A. U.; ABRÃO, D. C.; FACURY FILHO, E. J.; PAES, P. R. O.; RIBEIRO, M. F. B. Ocorrência de Trypanosoma vivax no estado de Minas Gerais. Arquivo Brasileiro de Medicina Veterinária e Zootecnia, Botucatu, v. 60, n. 3, p. 769-771, 2008.

COORDENAÇÃO DE INFORMAÇÃO E EPIDEMIOLOGIA. - CIEP. Analise dos informes epidemiológicos mensais. Disponível em: <http://www. adab.ba.gov.br/arquivos/File/Informes_2016/07. pdf>. Acesso em: 20 jan. 2017.
COSTA, V. M.; RIBEIRO, M. F.; DUARTE, A. L.; MANGUEIRA, J. M.; PESSOA, A. F.; AZEVEDO, S. S.; BARROS, A. T.; RIET-CORREA, F.; LABRUNA, M. B. Seroprevalence and risk factors for cattle anaplasmosis, babesiosis, and trypanosomiasis in a Brazilian semiarid region. Revista Brasileira de Parasitologia Veterinária, Jaboticabal, v. 22, n. 2, p. 207-213, 2013.

DAGNACHEW, S.; BEZIE, M. Review on Trypanosoma vivax. African Journal of Basic and Applied Sciences, Dubai, v. 7, n. 1, p. 41-64, 2015.

GARCÍA， H.; GARCÍA， M. E.; PÉREZ, G.; BETHENCOURT, A.; ZERPA, É.; PÉREZ, H.; MENDONZA-LEÓN, A. Trypanosomiais in Venezuelan water buffaloes: association of packed-cell volumes with seroprevalence and current trypanosome infection. Annals of Tropical Medicine and Parasitology, London, v. 100, n. 4, p. 297-305, 2006.

GUEDES, D. S. J.; ARAÚJO, F. R.; SILVA, F. J.; RANGEL, C. P.; BARBOSA NETO, J. D.; FONSECA, A. H. Frequency of antibodies to Babesia bigemina, $B$. bovis, Anaplasma marginale, Trypanosoma vivax and Borrelia burgdorferi in cattle from the Northeastern region of the State of Pará, Brazil. Revista Brasileira de Parasitologia Veterinária, Jaboticabal, v. 17, n. 2, p. 105109, 2008.

HURTADO,O.J.B.;CASTRO,P.D.J.; GIRALDO-RÍOS, C. Reproductive failures associated with Trypanosoma (Duttonella) vivax. Veterinary Parasitology, Amsterdam, v. 229, p. 54-59, 2016.

INSTITUTO BRASILEIRO DE GEOGRAFIA E ESTATÍSTICA - IBGE. Banco de dados agregados. Disponível em: <http://www.sidra.ibge.gov.br/>. Acesso em: 16 nov. 2016.

MARTINS, C. F.; MADRUGA, C. R.; KOLLER, W. W.; ARAUJO, F. R.; SOARES, C. O.; KESSLER, R. H.; MELO, E. S. P.; RIOS, L. R.; ALMEIDA, R. C. F.; LIMA, M. S. C.; BARROS, A. T. M.; MARQUES, L. C. Trypanosoma vivax infection dynamics in a cattle herd maintained in a transition area between Pantanal lowlands and highlands of Mato Grosso do Sul, Brazil. Pesquisa Veterinária Brasileira, Rio de Janeiro, v. 28, n. 1, p. 51-56, 2008.

PAIVA, F.; LEMOS, R. A. A.; NAKAZATO, L.; MORI, A. E.; BRUM, K. B.; BERNARDO, K. C. Trypanosoma vivax em bovinos no Pantanal do Estado do Mato Grosso do Sul, Brasil: Acompanhamento clínico, laboratorial e anátomopatológico de rebanhos infectados. Revista Brasileira de Parasitolologia Veterinária, Jaboticabal, v. 9, n. 2, p. 135-141, 2000. 
SEIDL, A.; DÁVILA, A. M. R.; SILVA, R. A. M. S. Estimated financial impact of Trypanosoma vivax on the Brazilian Pantanal and Bolivian lowlands. Memórias do Instituto Oswaldo Cruz, Rio de Janeiro, v. 94, n. 2, p. 269-272, 1999.

SILVA, R. A. M. S. Approach on risk factors of bovine trypanosomosis due to Trypanosoma vivax en the Bolivian and Brazilian Pantanals. Veterinária e Zootecnia, Botucatu, v. 13, n. 2, p. 153-162, 2006.
TURCATEL, M.; CARVALHO, C. J. B.; RAFAEL, J. A. Mutucas (Diptera: Tabanidae) do estado do Paraná, Brasil: chave de identificação pictórica para subfamílias, tribos e gêneros. Biota Neotropica, Campinas, v. 7, n. 2, p. 265-278, 2007.

ZAPATA, R.; MESA, J.; MEJÍA, J.; REYES, J.; RÍOS, L. A. Frecuencia de infección por Trypanosoma sp. en búfalos de agua (Bubalus bubalis) en cuatro hatos bufaleros de Barrancabermeja Colombia. Revista Colombiana de Ciencias Pecuarias, Antioquia, v. 22, n. 1, p. 25-32, 2009. 